bioRxiv preprint doi: https://doi.org/10.1101/2020.11.17.386896; this version posted November 17,2020 . The copyright holder for this preprint (which was not certified by peer review) is the author/funder, who has granted bioRxiv a license to display the preprint in perpetuity. It is made available under aCC-BY-NC-ND 4.0 International license.

\title{
Quantitative analysis of Histone modifications in gene silencing
}

Kenneth Wu\#, Namrita Dhillon\#, Kelvin Du and Rohinton T. Kamakaka*

Department of MCD Biology, 1156 High Street, University of California, Santa Cruz, CA

\section{USA}

E-mail: rohinton@ucsc.edu

\#These individuals contributed equally.

* corresponding author 


\begin{abstract}
Gene silencing in budding yeast is mediated by Sir protein binding to unacetylated nucleosomes to form a chromatin structure that inhibits transcription. This transcriptional silencing is characterized by the high-fidelity transmission of the silent state. Despite its relative stability, the constituent parts of the silent state are in constant flux giving rise to a model that silent loci can tolerate such fluctuations without functional consequences. However, the level of tolerance is unknown and we developed a method to measure the threshold of histone acetylation that causes the silent chromatin state to switch to the active state. We show that loss of silencing required between $50 \%$ and $75 \%$ of the unacetylated histones to be replaced with acetylated histone mimics. The precise levels of unacetylated nucleosomes required varied from locus to locus and was influenced by both silencer strength and UAS enhancer/promoter strength. Simple calculations suggest that an approximately $50 \%$ reduction in the ability of acetylases to acetylate individual nucleosomes across a large domain may be sufficient to generate a transcriptionally silent region in the nucleus.
\end{abstract}




\section{Introduction:}

Multiple loci in yeast are transcriptionally silenced including the cryptic mating type loci HML and HMR on chromosome III as well as sub-telomeric sites (Gartenberg and Smith, 2016). At $H M L$ and $H M R$, DNA elements called silencers serve as binding sites for specific proteins, which in turn recruit the repressor proteins Sir1, Sir2, Sir3 and Sir4 (Chien et al., 1993; Fox et al., 1997; Hecht et al., 1996; Liu and Lustig, 1996). The histones at silent loci lack acetylation or methylation marks (O'Kane and Hyland, 2019) though they are enriched in phosphorylated histone H2A (Kirkland and Kamakaka, 2013; Kitada et al., 2011). The Sir2/Sir4 heterodimer deacetylates $\mathrm{K} 9$ in histone $\mathrm{H} 3$ and $\mathrm{K} 16$ in histone $\mathrm{H} 4$ thereby facilitating Sir3 binding to the unmodified histone tails (Luo et al., 2002; Rusche et al., 2002). Sir3, in turn, simultaneously interacts with and stabilizes the binding of the Sir2/Sir4 heterodimer with nucleosomes thus generating a feedback loop that aids in further binding and spreading of the Sir proteins along the nucleosomal filament (Gartenberg and Smith, 2016). Sir protein interactions with nucleosomes hinder the association of the transcription machinery with regulatory sequences thereby establishing the transcriptionally silent state at $H M L$ and $H M R$.

Besides the silencers and the Sir proteins, the post-translational modifications of the histones play a critical role in silencing. Studies utilizing various histone mutants have shown that a region of the histone $\mathrm{H} 4 \mathrm{~N}$-terminal tail from $\mathrm{K} 16$ to $\mathrm{K} 20$ is critical for silencing. In addition, a H4K16Q mutant (which is an acetyl mimic) results in a dramatic loss of silencing (Carmen et al., 2002; Hyland et al., 2005; Lin et al., 2008; Millar et al., 2004; Shahbazian and Grunstein, 2007; Yu et al., 2011) and Sir3 binding is dependent upon the deacetylation of this residue (Ehrentraut et al., 2011; Johnson et al., 1992; Johnson et al., 1990; Onishi et al., 2007; Wang et al., 2013). These data show that the absence of acetyl groups on $\mathrm{K} 16$ is crucial for silencing. However, it is currently unknown whether specific nucleosomes have to be unacetylated for silencing or whether a majority of nucleosomes across the entire domain-have to be unacetylated for silencing. 
Once established, the silent state is stably maintained for several generations (Gottschling et al., 1990; Pillus and Rine, 1989; Sussel et al., 1993). Occasional disruptions in silencing do occur but are rare: One in a thousand cells stochastically lose silencing at $H M L$ while $~$ seven in ten thousand cells stochastically lose silencing at $H M R$. It is presumed however, that the active state at these loci is short-lived before the silenced state is restored (Dodson and Rine, 2015).

Despite the high fidelity of the inheritance of the silent state, studies suggest that the individual components of silenced chromatin are not stably bound but in constant flux. While the exchange of the core histones in chromatin is quite slow, except at specific regulatory elements (Dion et al., 2007; Misteli et al., 2000), the covalent modifications of the histones have half-lives of only a few minutes (Waterborg, 2001, 2002). While the presence of the Sir3 repressor is essential for silencing (Cheng et al., 1998; Miller and Nasmyth, 1984), analysis of heterochromatin and heterochromatic proteins indicates that repressor protein binding is also dynamic and is influenced by the acetylation and methylation state of the underlying chromatin (Cheng and Gartenberg, 2000; Cheutin et al., 2003; Festenstein et al., 2003). Thus, the overall picture is of a phenotypically stable silenced chromatin state being mediated by constituents that are in constant flux.

Adding further to the complexity of this molecular turmoil is an additional challenge that the cell must overcome to maintain silencing with high fidelity: DNA replication results in a near complete disruption of the chromatin state. Nucleosomes are unable to bind single-stranded DNA (Almouzni et al., 1990) and nucleosomal histones are evicted upstream of the replicating fork (Sogo et al., 1986) and redeposited downstream (Gasser et al., 1996). During DNA replication, nucleosome positions and DNasel hypersensitive sites (which are sites for binding of transcription factors) are disrupted (Lucchini et al., 2001; Solomon and Varshavsky, 1987; Vasseur et al., 2016) and following replication, the maturation of chromatin leads to the resetting of the original chromatin state (Annunziato and Seale, 1983; Bar-Ziv et al., 2016; Vasseur et al., 2016). The vast majority of the $\mathrm{H} 3 / \mathrm{H} 4$ parental tetramers are transferred intact but randomly 
onto one of the two daughter strands while the parental $\mathrm{H} 2 \mathrm{~A} / \mathrm{H} 2 \mathrm{~B}$ dimers segregate randomly to the daughter strands (Annunziato, 2015; MacAlpine and Almouzni, 2013; Mello and Almouzni, 2001). Besides the replication mediated disruption of chromatin structure, the duplication of the DNA also results in the dilution of the parental histone complement by half. The twofold reduction in nucleosome number is restored by newly synthesized histones. Newly synthesized histones are decorated such that histone $\mathrm{H} 4$ is acetylated on $\mathrm{K} 5$ and $\mathrm{K} 12$ and histone $\mathrm{H} 3$ is acetylated on K9 and K56 (Benson et al., 2006; Ling et al., 1996; Masumoto et al., 2005; Sobel et al., 1995). The maturation of chromatin following replication involves the removal of these deposition specific modifications of the histones, and the restoration of the modifications found in the mother cell (Bar-Ziv et al., 2016).

The chromatin state that is disrupted during replication, creates a temporal window in the G2 phase of the cell cycle where silenced chromatin is more accessible to enzymatic probes (Aparicio and Gottschling, 1994; Cheutin et al., 2003; Lau et al., 2002) and thus more prone to disruption. Counteracting this disruption are the silencer elements. Elimination of the silencers result in the inability of the silent state to reform following its disruption in S-phase (Cheng and Gartenberg, 2000). Furthermore, efficient inheritability of silencing requires the silencer bound proteins Rap1 and Sir1 (Pillus and Rine, 1989; Sussel et al., 1993).

Besides the silencers, models have invoked a role for histone modification marks in the heritability of the silent state. In silico models (Mukhopadhyay and Sengupta, 2013; Sneppen and Dodd, 2012, 2015) suggest that stable inheritance of silencing involves parental modified nucleosomes helping in the templating and modification of nucleosomes containing newly synthesized histones. These models suggest that the efficient inheritance of silenced chromatin likely involves Sir protein binding to unacetylated parental nucleosomes followed by the deacetylation of spatially adjacent newly synthesized histones. The data have also led to a buffer model for the inheritance of the silent state (Huang et al., 2013) which suggests that the silent locus can tolerate significant fluctuations in acetylation levels of the histones during 
bioRxiv preprint doi: https://doi.org/10.1101/2020.11.17.386896; this version posted November 17,2020 . The copyright holder for this preprint

(which was not certified by peer review) is the author/funder, who has granted bioRxiv a license to display the preprint in perpetuity. It is made available under aCC-BY-NC-ND 4.0 International license.

replication. The occasionally acetylated nucleosome at the silent locus does not lead to a loss of silencing but silencing is lost when a particular threshold of acetylation is reached. The level of tolerance in the system is unknown and experiments measuring this are currently lacking. To understand the quantitative relationships between $\mathrm{H} 4 \mathrm{~K} 16$ acetylation levels and the inheritance of silencing, we developed an assay to quantitatively alter $\mathrm{H} 4 \mathrm{~K} 16$ acetylation levels and measure the effects of these changes on silencing. 


\section{Materials and Methods:}

\section{Protein Blots}

Protein lysates were prepared and resolved on a 15\% SDS-polyacrylamide gel as described previously (Ghidelli et al., 2001), except that glass beads were used to break open the cells.

\section{RT-qPCR}

Total RNA was isolated from yeast cells as described (Schmitt et al., 1990). cDNA was prepared using the reverse transcription-PCR kit.

\section{Fluorescence activated cell sorting analysis}

Cells were washed in 50mM Tris-HCL, pH7.5 and fixed in $70 \%$ ethanol for $1 \mathrm{~h}$ at room temperature. Cells were then washed in $50 \mathrm{mM}$ Tris-HCL, $\mathrm{pH} 7.5$ and treated with $1 \mathrm{mg} / \mathrm{ml}$ RNase $\mathrm{A}$ at $37^{\circ} \mathrm{C}$ for $1 \mathrm{~h}$ followed by ProteinaseK treatment $(60 \mathrm{ug} / \mathrm{ml})$ at $55^{\circ} \mathrm{C}$ for $1 \mathrm{~h}$. Cells were washed and resuspended in phosphate-buffered saline, filtered through a Nitex membrane and stained with Sytox Green stain. Flow cytometry was performed at the UCSC cytometry facility.

Fluorescence Microscopy: Cells were grown exponentially in yeast peptone (YP) medium with $2 \%$ raffinose at $30^{\circ} \mathrm{C}$ to an $\mathrm{OD}_{600}$ of around 1 . The culture was back-diluted to an $\mathrm{OD}_{600}$ of $0.125 / \mathrm{mL}$ in YP medium with $5 \mu \mathrm{M}$ alpha-factor and $2 \%$ raffinose and incubated on a shaker at $30^{\circ} \mathrm{C}$. After 3 hours, the cells were pelleted and transferred into yeast minimal (YM) medium with $5 \mu \mathrm{M}$ alpha-factor, $2 \%$ galactose with appropriate amino acid supplements and incubated on a shaker at $30^{\circ} \mathrm{C}$ for 4 hours. Cells were pelleted, washed with medium lacking alpha factor, and transferred into YM medium with $2 \%$ dextrose and amino acid supplements. Cells were grown on a shaker at $30^{\circ} \mathrm{C}$ and aliquots removed at appropriate times. After $7 \mathrm{~h}$, the culture was diluted with fresh medium and allowed to grow for another $10 \mathrm{~h}$ at $30^{\circ} \mathrm{C}$ until the final time point. 
For each time point, $1 \mathrm{~mL}$ of sample was removed and the cells were pelleted and resuspended in $20 \mathrm{uL} \mathrm{YM} 2 \%$ dextrose medium. $3 \mathrm{uL}$ of the suspension was applied to a 1.5\% agarose YMD pad on top of a microscope slide and cover-slipped. Images were acquired on a DeltaVision Personal DV system (Applied Precision), using a 40x 1.35 NA oil-immersion objective (Olympus), with a CoolSnap charge-coupled camera (Roper Scientific). $4 \mu \mathrm{m}$ image stacks were collected, with each Z-image being $0.2 \mu \mathrm{m}$ apart, $2 \mu \mathrm{m}$ above and below the plane of focus. Image stacks were taken for each time point and greater than 100 cells were captured across the fields-of-view.

Image analysis was performed using the FIJI distribution of ImageJ software. To measure fluorescence intensity per cell, a two-dimensional maximum-intensity projection was generated for each collected z-stack. A transmitted light image, taken at the center of each z-stack, was overlaid on top of the projection. The transmitted light image served as a guide to establish cell boundaries for maximum-intensity projections, such that maximum fluorescence intensity data could be collected per cell using the software's measuring tool. Data for approximately 100 cells per time point were collected, compiled into a spreadsheet, and graphed using $\mathrm{R}$ software with ggplot2 package.

Chromatin Immunoprecipitation: Cells were grown in YPD media to an $\mathrm{OD}_{600 \mathrm{~nm}}$ of 2.0 and then fixed with $1 \%$ formaldehyde for $10 \mathrm{~min}$. Cells were collected, resuspended in buffer and sonicated using the Bioruptor (Diagenode, Belgium) followed by a cup-horn (Branson, USA) sonicator to an average size of 300bp.

Immunoprecipitation reactions were performed with commercial antibodies to histone H3, Ac-K16 H4 (Millipore, USA), Ac-K56-H3 (Millipore, USA) or with polyclonal anti-Sir3 antibodies and immune complexes were collected with Protein G/A beads (Calbiochem, EMD Biosciences). Immunoprecipitated and input DNA were purified using Chelex 100 (Bio-Rad) (Nelson et al., 2006) and the amount of DNA was quantified using the Picogreeen dsDNA 
quantitation kit (Invitrogen, USA) and the PerkinElmer Viktor ${ }^{3}$ Fluorescence Reader, prior to qPCR.

Equal amounts of IP DNA and input DNA were used for the qPCR reactions. Quantitative PCR reactions were carried out in a Rotor Gene 6000 with SYBR Green (Platinum SYBR Green qPCR SuperMix UDG, Invitrogen) and a three-step PCR program.

The fold difference between immunoprecipitated DNA (IP) and Input DNA for each qPCR amplified region were calculated as described (Litt et al., 2001), using the formula $\mathrm{IP} / \mathrm{Input}=\left(2^{\mathrm{InputCt}-\mathrm{IPCt}}\right)$. Each experiment involved at least two independent crosslinked samples with each sample immunoprecipitated twice with the same antibody. 


\section{Results:}

\section{Histone acetylation is reduced over the silenced domain}

We first characterized the chromatin state of the silenced locus in G1-arrested cells to determine the levels of various proteins and modifications at the silenced locus (Figure 1). Using ChIP qPCR, we mapped the relative abundance of core histone H3, Sir3, histone H4K16 acetylation and $\mathrm{H} 3 \mathrm{~K} 56$ acetylation at the silent $H M R$ locus. Mapping histone $\mathrm{H} 3$ showed that a site between the two silencers located within the silenced domain had a normal complement of histones as did a site in the euchromatic GIT1 gene (Figure 1). The silencers as well as the tDNA barrier were moderately "nucleosome-free" as expected though the weaker than expected depletion of nucleosomes is probably due to the average size of the immunoprecipitated DNA ( 300 bp) (Cole et al., 2012a; Cole et al., 2012b; Dhillon et al., 2009; Dion et al., 2007; Oki and Kamakaka, 2005).

Conversely, Sir3 was maximally present at the two silencers while its binding was reduced at the tDNA boundary of the silent domain and at a site within the silent domain which was consistent with previous observations (Thurtle and Rine, 2014; Valenzuela et al., 2008).

We next quantified the distribution of histone acetylation on H3K56 and H4K16 (Figure 1). Since the silencers and the tDNA barrier are depleted of histones we normalized the distribution data for these modifications to histone occupancy, thereby showing whether or not there is enrichment or depletion of these modifications on a per- "nucleosome" basis. On a per nucleosome basis, H3K56 acetylation levels showed significant reduction across the entire silent domain and there were even lower amounts of $\mathrm{H} 4 \mathrm{~K} 16$ acetylation at these sites. The data showed that less than $10 \%$ of the histones at the silent locus were acetylated on H4K16 in cells arrested in the G1 phase of the cell cycle.

\section{Design of the Cut and Flip system}


We next investigated the quantitative relationship between histone H4K16 acetylation and gene silencing. Previous work on histones have used one of two different approaches. In one approach, the wild type and mutant histone genes (with their own regulatory elements) are present on plasmids, and the mutant is compared to the wild type strain via plasmid shuffle (Han et al., 1988; Kayne et al., 1988). This system is neither inducible nor tunable and so one is unable to observe the switch or study transition states. In addition, the histone genes are present on plasmids, which fluctuate in copy number from cell to cell. In the second approach, the histone genes are under the control of heterologous enhancer/promoter which can be induced by galactose (Dion et al., 2007). With this approach the histone gene is expressed at high levels throughout the cell cycle in place of its normally restricted expression in the G1/S phase (Eriksson et al., 2012) and this is known to trigger cell cycle checkpoints (Gunjan and Verreault, 2003) and lead to dominant effects (Meeks-Wagner and Hartwell, 1986).

We therefore developed a system to overcome these issues. In S. cerevisiae there are two histone loci for the histone H4- HHF1 and HHF2. We constructed a strain lacking the HHF1 locus and where the wild type histone HHF2 locus was modified to accommodate two copies of the $\mathrm{H} 4$ coding sequence (Figure2A). $\mathrm{R}$ recombinase recognition sites flanked the coding region of the wild type $\mathrm{H} 4$ gene that had an $\mathrm{HA}$ tag at its $\mathrm{N}$-terminus. Immediately downstream of the wild type allele, we inserted a copy of an acetylation mimic mutant of the histone $\mathrm{H} 4$ gene fused to an N-terminal Myc tag. This mutant allele lacked the HHF2 enhancer/promoter element and therefore was not transcribed. The strain also contained the R-recombinase under the control of the GAL1 enhancer/promoter. The R-recombinase mediated flipping is a rapid and efficient method of creating a desired deletion (Li et al., 2001).

The experiment involved growth of yeast cells expressing the wild-type $\mathrm{H} 4$ gene from its own UAS enhancer/promoter. Cells were arrested in G1 and the R-recombinase was induced by switching the carbon source to galactose. The recombinase induced recombination between the two $\mathrm{R}$ recognition sites flanking the wild type $\mathrm{H} 4$ gene which resulted in the flipping out 
(deleting) of the wild type $\mathrm{H} 4$ copy thereby bringing the mutant $\mathrm{H} 4$ gene in register with its native UAS enhancer/ promoter. Since the mutant $\mathrm{H} 4$ gene is brought under the control of its native UAS enhancer, the mutant protein is expressed only during the G1/S phase of the cell cycle and not over-produced and since the modified histone cassette is present at its native locus on chromosome 14, it does not suffer from changes in copy number.

\section{Characterization of the Histone H4 Cut and Flip}

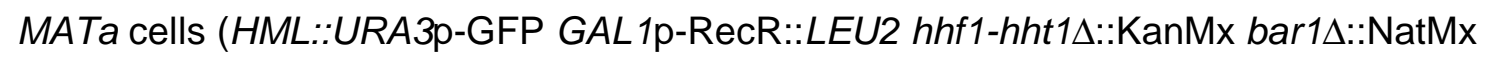
HHF2p-R-HA-HHF2-R-Myc-hhf2K16Q) were grown overnight in raffinose containing rich medium and arrested in the G1 phase of the cell cycle for 3 hours with alpha factor. We monitored arrest by microscopy (data not shown) as well as by flow cytometry (Figure 2B). Once cells had arrested in the G1 phase of the cell cycle, we shifted the cells to galactosecontaining media to induce the R-recombinase. We ascertained that four hours of incubation in galactose were sufficient for maximal R-recombinase mediated switching of the HHF2 alleles (data not shown). Cells were then released from the G1 arrest into dextrose containing media and aliquots of the cells were removed for further analysis.

Cytometry of the yeast cells (Dhillon et al., 2006) showed that all cells were arrested uniformly in G1. The analysis of these cells following their release from G1 arrest helped us identify the time for each S-phase and showed that the first S-phase occurred around 30 minutes (Figure 2B). The data also showed that most cells progressed through the second Sphase between 2 and 3 hours after their release, albeit with reduced cell-cycle synchrony.

We next monitored the switch of the wild type to mutant HHF2 alleles by protein blots using antibodies against the HA and Myc epitopes (Figure 2C). Protein extracts were prepared from approximately equal number of cells at each time point and the proteins were resolved on a $15 \%$ SDS-Polyacrylamide gel. The proteins after transfer to nitrocellulose membranes were probed with antibodies against HA, Myc or histone H2B. In G1 arrested cells, the predominant histone $\mathrm{H} 4$ protein was $\mathrm{HA}$ tagged wild type protein. Following release, the levels of histone $\mathrm{H} 4$ 
containing the HA epitope reduced with a concomitant increase in the levels of mutant histone H4-Myc protein. We also monitored the levels of histone H2B as a control and as expected this protein remained relatively unchanged. The protein blots thus demonstrated that the switch cassette functioned as designed.

We then wished to determine if the switched histone $\mathrm{H} 4 \mathrm{~K} 16 \mathrm{Q}$ mutant proteins were being incorporated into chromatin. Cells arrested in galactose as well as cells collected 2 and 4 hours after release from the G1 phase of the cell cycle were crosslinked with formaldehyde and the crosslinked chromatin was immunoprecipitated using anti-HA and anti-Myc antibodies (Figure 3). Each experiment was performed with a minimum of two independently crosslinked samples and each sample was immunoprecipitated at least twice with the same antibody. The binding of the tagged histones at three different silent loci- $H M L, H M R$ and telomere $6 \mathrm{R}$, was monitored by qPCR. The data showed that the levels of wild type histone H4-HA bound to these loci decreased following release from alpha-factor arrest (Figure 3 top panels), and the levels of mutant histone H4-Myc increased upon release (Figure 3 bottom panels).

Having shown that following the switch, mutant histone protein does become incorporated into silenced chromatin, we next investigated the effects of the switch in histones on silenced chromatin using qChIP with antibodies against Sir3 (Figure 4A). In G1 arrested cells, Sir3 was bound to all three silenced loci- HML, HMR and TEL6R. Upon release from the G1 arrest, Sir3 levels reduced within $2 \mathrm{~h}$ and there was very little Sir3 bound to these loci after $4 \mathrm{~h}$ showing that incorporation of the mutant histone lead to a loss of Sir3 binding and presumably the activation of the genes at these loci.

As a second measure of silencing loss, we measured mRNA levels of a GFP reporter present at HML using RT-qPCR (Figure 4B). We isolated mRNA from G1 arrested cells as well as from cells at 2- and 4-hours post-release and measured levels of GFP mRNA along with actin mRNA. In G1-arrested cells there was very little GFP mRNA compared to actin mRNA consistent with the locus being silenced. However, upon release from the arrest, we observed a 
large increase in GFP expression at the $2 \mathrm{~h}$ time point which further increased at the $4 \mathrm{~h}$ time point.

\section{Fluorescence measurements of gene silencing}

Molecular approaches often mask nuance and heterogeneity in data. While one can use mating ability to monitor silencing of the native genes at $H M L$ and $H M R$, this assesses the silent state only in the G1 phase of the cell cycle and is challenging to monitor in single cells. A fluorescent protein reporter at these loci would circumvent these limitations. We analyzed expression of GFP reporters inserted at $H M L, H M R$ and a telomere using fluorescence microscopy along with the cut and flip cassette. The GFP reporter we employed was a previously characterized, rapidly folding protein (folding/maturation time of $\sim 20 \mathrm{~min}$ ) with a high turnover rate (half-life of $\sim 35 \mathrm{~min}$, due to the presence of a CLN2 PEST sequence) that localized to the nucleus (due to the presence of a nuclear localization signal) (Osborne et al., 2009; Osborne et al., 2011; Xu et al., 2006). We integrated the GFP reporter under the control of either the URA3 UAS enhancer/promoter or the alpha2 UAS enhancer/promoter at either the $H M L$ or $H M R$ loci or $T E L 7 L$.

We first built a set of strains expressing either the wild type $\mathrm{H} 4$ or $\mathrm{H} 4 \mathrm{~K} 16 \mathrm{Q}$ mutant protein alone. These strains also contained $H M L$ and $H M R$ loci expressing a GFP reporter under the control of the URA3 and alpha2 UAS enhancer and core promoter. We measured the GFP signal in at least 100 cells in these strains using a fluorescent microscope (Figure 5A). In cells expressing only the wild type histone $\mathrm{H} 4$ protein, we did not observe any GFP fluorescent signal from HMR::URA3p-GFP, HMR::alpha2p-GFP, HML::URA3p-GFP or HML::alpha2p-GFP. In cells expressing only the mutant $\mathrm{H} 4 \mathrm{~K} 16 \mathrm{Q}$ protein, GFP fluorescence signal was robust and easily detected as predicted for this mutation (Johnson et al., 1990; Lin et al., 2008; Yu et al., 2011). The absolute levels of detected fluorescence in the $H 4 \mathrm{~K} 16 \mathrm{Q}$ mutant varied both, with the silent locus and the UAS enhancer/promoter. At HMR, we consistently saw higher GFP signal when it was under the control of the URA3 UAS enhancer/promoter compared to the alpha2 
UAS enhancer/promoter and we saw a similar expression pattern at HML. Interestingly, comparing $H M R$ to $H M L$, we observed greater derepression of the reporter at $H M L$ than $H M R$, as well as greater variation in expression of the reporter at $H M L$ compared to $H M R$. These data suggest that both UAS enhancer/promoter and silencer strength together influence expression levels of the genes at these silenced loci.

We also wished to confirm that the act of switching the histones did not perturb the silent state. We generated a cut and flip HHF2 strain where the wild type $\mathrm{H} 4$ could be switched to another wild type H4 (HHF2p-R-HA-HHF2-R-Myc-HHF2). Cells were arrested in G1, the cassette was switched and then cells were released into the cell cycle. GFP expression at $H M L:: U R A 3 p-G F P$ was then measured over time (Figure 5B). We did not observe any changes in GFP fluorescence upon switching of the histones; therefore, the histone switch in and of itself did not affect silencing.

To determine the quantitative relationship between $\mathrm{H} 4 \mathrm{~K} 16 \mathrm{Q}$ levels at the silent loci and gene silencing, we employed strains where the wild-type $\mathrm{H} 4$ could be switched to a mutant H4K16Q. We arrested these cells in G1, switched the histone alleles using R-recombinase and then released these cells from the G1 arrest and monitored expression of GFP by fluorescence microscopy. At $H M L$, when GFP was under control of the URA3 UAS enhancer/promoter, measurable fluorescent signal was observed $2 \mathrm{~h}$ after release from $\mathrm{G} 1$ arrest and reached maximal levels around $5 \mathrm{~h}$. These data suggest that silencing was beginning to be lost during or soon after the second S-phase (Figure 6A).

When we measured GFP expression under the control of the alpha2 UAS enhancer/promoter at $H M L$, measurable fluorescence was first observed around the $4 \mathrm{~h}$ time point with maximal expression occurring around the $7 \mathrm{~h}$ time point indicating that silencing was beginning to be lost in or after the third S-phase (Figure 6B).

We saw similar dynamics for the HMR locus. When the GFP reporter was under the control of the URA3 UAS enhancer/promoter, we saw measurable GFP signal approximately $3 \mathrm{~h}$ 
after the release while for the alpha2 UAS enhancer/promoter, GFP signal was first observed $4 \mathrm{~h}$ after the release (Figure 6C and 6D).

We also analyzed silencing at telomere $7 \mathrm{~L}$. The GFP reporter under the control of the URA3 UAS enhancer/promoter was inserted adjacent to TEL7L. Cells were arrested in G1, the histone allele was switched and GFP expression was measured after release. A measurable fluorescent signal was observed within $1 \mathrm{~h}$ after release suggesting that $\sim 50 \%$ replacement of wild type $\mathrm{H} 4$ with $\mathrm{H} 4 \mathrm{~K} 16 \mathrm{Q}$ was sufficient for weakening the silent state at this locus (Figure $7 \mathrm{~A}$ ).

It is possible that for $H M L$ and $H M R$, silencing in some cells begins to be lost at early time points but the increases in expression went undetected due to the limitations in the sensitivity of our fluorescent measurement set up. We nevertheless observed quantifiable loss-of-silencing at $T E L 7 L$ at these early time points, showing that the telomeres are more susceptible to changes in histone acetylation than the cryptic mating type loci and the inability to detect GFP signal from $H M L$ and $H M R$ at early time points is not due to the time required for the maturation of the GFP fluorescent signal.

In this study we quantified silencing by measuring levels of GFP fluorescent signal in individual live yeast cells. The actual time when silencing is lost and transcription initiates from the silent locus will be different from the time when GFP fluorescent signal is detected by microscopy. The GFP mRNA is $\sim 1000$ bases long and with a yeast transcription elongation rate of 25 bases/second (Pelechano et al., 2010) would be transcribed within $\sim 40$ seconds. The yeast translation rate is 2.63 amino acids/second (Riba et al., 2019) and so GFP would be translated in $\sim 2$ minutes. The maturation time of the GFP protein used in this study is $\sim 20$ minutes (Osborne et al., 2009; Osborne et al., 2011; Xu et al., 2006) and thus detection of the GFP fluorescent signal would be delayed $\sim 23$ minutes from the actual time of loss of silencing. Since we used one-hour time points for our fluorescence measurements, we do not believe that this offset prevents us from correlating our observations to cell cycle events. 
Our results showed that at $H M L$ and $H M R$, silencing was not lost after the first S-phase but weakened during or after the second S-phase, when the wild type H4 levels should have dropped to at least $25 \%$. To confirm this result we built a cut and flip HHT2-HHF2 strain that contained the wild type HHT1-HHF1 alleles, thereby halving the fold-reduction of the wild type H4 with each DNA replication event. In this strain, the percent of chromatin-bound H4K16Q would approximately be $25 \%$ after the first S-phase, increase to $37.5 \%$ after the second Sphase and approach 50\% after successive S-phases. We arrested this strain in G1, switched the HHF2 allele from wild type to $\mathrm{H} 4 \mathrm{~K} 16 \mathrm{Q}$, and monitored expression of the URA3 UAS enhancer/promoter driven GFP reporter at $H M L$ (Figure 7B). In this strain, we did not observe expression of GFP after switching the HHF2 alleles from wild type to mutant suggesting that greater than $50 \% \mathrm{H} 4 \mathrm{~K} 16 \mathrm{Q}$ histones need to be incorporated at $H M L$ before a quantifiable GFP fluorescent signal can be observed. 


\section{Discussion:}

The silencer and silencer bound proteins are necessary for efficient inheritance of the silent state (Cheng and Gartenberg, 2000; Pillus and Rine, 1989; Sussel et al., 1993). The key role of the silencers is to maintain a high concentration of Sir proteins in the vicinity of the locus for the state to be re-established after its disruption during replication. It is likely that silencer strength influences the efficiency of inheritance since we consistently observe greater silencing mediated by the $H M R$ silencers compared to the $H M L$ silencers in agreement with previous observations about silencer strengths (Shei and Broach, 1995).

In addition to the silencer, efficient inheritance of the silent state depends upon the nucleosomes remaining unacetylated. There are approximately 20 and 12 nucleosomes present at $H M L$ and $H M R$ respectively (Ravindra et al., 1999; Weiss and Simpson, 1998). While it is possible that the deacetylation of a single key nucleosome is necessary for silencing, our data argue against this. We support a model where the locus requires an aggregate level of acetylated nucleosomes for silencing to be lost. In this scenario, a domain would remain silent so long as the number of unacetylated nucleosomes are above a certain threshold. The silent locus can thus tolerate fluctuations in overall acetylation levels without functional consequence. Our data suggest that for $H M L$ and $H M R$ to lose silencing, around $75 \%$ of the nucleosomes must acquire acetyl marks before the locus loses silencing. That acetylation of $50 \%$ to $75 \%$ nucleosomes causes loss of silencing is also consistent with biochemical data showing that Sir proteins are able to interact with unacetylated histone tails in one nucleosome and bridge neighboring nucleosomes leading to silencing (Behrouzi et al., 2016; Ehrentraut et al., 2011; Ghidelli et al., 2001; Johnson et al., 1992; Onishi et al., 2007; Wang et al., 2013).

The bulk of the yeast nucleus is packaged into euchromatin and consistent with this is the observation that almost every histone H4 molecule is acetylated (Hecht et al., 1995; Kuo et al., 1998; Waterborg, 2001). The exception to this is the silent loci where histone H4 molecules are not acetylated. If one assumes for simplicity's sake that H4K16 acetylation is required for the 
spontaneous loss of silencing, then our data can be used to calculate the probability of a stochastically spontaneous acetylation of a nucleosome at the silent locus. At the native silenced loci, silencing is stochastically lost in one out of every 1000 cells at $H M L$ with a similar value at $H M R$ (Dodson and Rine, 2015). Based on our data, for one cell out of 1000 to spontaneously lose silencing, $75 \%$ of the nucleosomes would need to acquire H4K16 acetylation in that cell. Therefore, at HML, for 15 out of the 20 nucleosomes $(75 \%)$ to be simultaneously acetylated, a single nucleosome would have a $\sim 1 / 1.6(60 \%)$ probability of acquiring an acetyl group by chance. These numbers suggest that just a small reduction in the ability of acetylases to acetylate nucleosomes across a contiguous stretch of DNA may be sufficient to generate a transcriptionally silent region in the nucleus. The precise number would likely vary from cell to cell since other factors such as the local concentration of the Sir proteins, transcription activators and modifications of other histone residues (such as H3K56 and H3K79) are also likely to fluctuate and affect the overall process.

\section{Replication and acetylation}

Silencing is a dynamic equilibrium state and the key determinants for resetting the silent domain following replication would be the relative local concentrations of transcription activators (and coactivators) and repressor (and corepressor) proteins at these loci (Aparicio and Gottschling, 1994; Donze et al., 1999; Renauld et al., 1993; Shei and Broach, 1995; Valenzuela et al., 2009). While silencing is mediated by proteins in constant flux, it is nevertheless stable and faithfully propagated through growth and cell division. There are likely many different factors that collectively lead to this high fidelity. The parental histones segregate randomly to the replicated daughter strands and in theory parental histones with active modifications (such as H4K16 acetyl) could ingress into the silenced domain and aid in the switch from silent to active state. However, while parental histones are evicted from the DNA during replication, they are redeposited in close proximity to their original site, thereby reducing the probability of histones with active modifications being transferred to silenced chromatin (Jackson and Chalkley, 1985; 
Radman-Livaja et al., 2011). Moreover, active chromatin is replicated early while silenced loci are replicated late (Friedman et al., 1995; Raghuraman et al., 2001) and this temporal separation would further reduce the likelihood that silent loci would become bound by parental histones containing active chromatin marks. It is also highly unlikely that silent loci acquire acetyl marks from newly synthesized histones, since newly synthesized histone $\mathrm{H} 4$ is acetylated on K12 and not K16 (Ai and Parthun, 2004; Sobel et al., 1995). In addition, the presence of the silencers increases the local concentration of the Sir proteins compared to the global nuclear distribution of Sas2 acetylase throughout the nucleus, thus reducing the probability of nucleosome acetylation and favoring the deacetylated state at silent loci. Lastly, the threedimensional clustering of silent loci (Kirkland and Kamakaka, 2013; Maillet et al., 1996) could create a pinball effect, trapping Sir proteins in the vicinity of the silent loci and increasing the effective local concentration of the Sir proteins at these loci. While Sir2 removes acetyl groups from nucleosomes that stochastically acquire the modifications because of the global presence of Sas2, the primary function of the other Sir proteins is likely the prevention of acetylation of the histones following their deposition onto newly replicated DNA.

\section{Binary versus Analog silencing}

Silencing has classically been shown to be an all-or-nothing phenomenon: a locus is either fully silent or active (Gottschling et al., 1990; Pillus and Rine, 1989). An interesting observation from our studies is that during the loss of silencing at early time points we did not observe a digital "binary" response in the levels of GFP protein. When we measured the amount of GFP fluorescence in individual cells, we observed a continuum of values. If one assumes a proportional relationship between mRNA levels and protein levels, and also assumes that the expression of the mating type transcription factors is similar to GFP expression, then the levels of GFP observed in hundreds of individual nuclei do not show a bimodal distribution suggesting that loss of silencing was not an all-or-nothing phenomenon and in a population of cells loss of 
silencing generates a continuum of mRNA (Dodson and Rine, 2015) and protein levels that, at the level of a phenotype, (ability to mate) translates into a binary choice- mating or non-mating.

The implications of a partially silent state are variable levels of GFP proteins in individual cells at these early time points. One possibility to explain this phenomenon is that transcription is noisy and occurs in bursts. If one assumes that transcription is a probabilistic event then partial silencing could be due to changes in transcription burst frequency or burst size (Otto, 2019; Rodriguez and Larson, 2020; Wang et al., 2018). This, in turn, would be determined by accessibility of the UAS enhancer and core promoter to the transcription machinery. Access could be affected by altering the affinity of the transcription factors for their binding sites via post-translational modifications of these proteins or by the modifications of nucleosomes leading to changes in the positioning of nucleosomes over the binding sites as well as by altering the ability of chromatin remodelers to evict or slide nucleosomes. Thus, the role of the Sir proteins in transcriptional silencing would be to alter the probability of transcription activator and general factor binding to the UAS enhancer and core promoter, as well as alter the ability of chromatin remodelers to slide or evict nucleosomes. 


\section{Figure Legends:}

\section{Figure 1:}

ChIP qPCR of various proteins in G1 arrested cells.

Histone H3, Sir3, H4K16 acetylation and H3K56 acetylation levels was measured across the HMR domain. Data is presented as the mean enrichment of IP/Input (as described in the materials and methods) for at least four IPs from two independent cross-links. Error bars are standard deviation from the mean. The data for H3K56 acetylation and H4K16 acetylation are presented as enrichment normalized to histone $\mathrm{H} 3$ enrichment in order to take into account variable levels of nucleosome occupancy.

Figure 2:

A: $\quad$ Schematic of the Histone $\mathrm{H} 4$ cut and flip cassette

B: $\quad$ G1 arrest and release fluorescence cytometry profiles of the Cut and Flip strain.

Ethanol fixed cells were stained with Sytox Green and analyzed by flow cytometry.

Panel 1: Fluorescence cytometry profile of asynchronously growing cells in raffinose containing medium. Panel 2: Fluorescence cytometry profile of cells arrested with alpha factor in galactose containing medium. Panels 3 to 6 : Fluorescence cytometry profile of cells at the indicated times after release from alpha factor arrest into glucose containing media.

C: $\quad$ Protein immunoblot analysis of cells arrested with alpha factor and released after switching of histone $\mathrm{H} 4$ alleles.

Yeast cells were grown overnight in raffinose containing rich medium, arrested with alpha factor for $3 \mathrm{~h}$ and then transferred to galactose containing medium with alpha factor for $4 \mathrm{~h}$. Cells were released into YPD and aliquots of equivalent numbers of cells were removed at the specified times. Protein extracts were separated on a 15\% SDS-polyacrylamide gel, transferred to membranes and probed with specific antibodies.

\section{Figure 3:}

ChIP qPCR of unswitched and switched histone $\mathrm{H} 4$ at the silenced loci. 
The presence of wildtype HA-H4 and mutant Myc-H4 K16Q protein was monitored by ChIP in unswitched and $2 \mathrm{~h}$ and $4 \mathrm{~h}$ after switching of the histone $\mathrm{H} 4$ allele. The $\mathrm{Y}$-axis represents the ratio of IP/Input DNA for each sample as described in the materials and methods. The levels of the tagged proteins were mapped at three different loci- $H M L, H M R$ and TEL6R.

\section{Figure 4:}

ChIP qPCR measurement of Sir3 binding at silenced loci following switch of WT H4 to H4K16Q mutant

A: $\quad$ Sir3 binding at $H M L, H M R$ and TEL6R was monitored using ChIP-qPCR in cells arrested with alpha factor and at $2 \mathrm{~h}$ and $4 \mathrm{~h}$ after switching the histone $\mathrm{H} 4$ allele and alpha factor release. Data is presented as the mean enrichment of $\mathrm{IP} / \mathrm{Input}$.

B: $\quad$ Measurement of mRNA expression of the GFP reporter at $H M L$ before and after switch of the histone $\mathrm{H} 4$ alleles.

Alpha factor arrested cells and cells released into rich medium were collected at $2 \mathrm{~h}$ intervals and total RNA was extracted from these cells. GFP mRNA was quantitated by RTqPCR and plotted as a function of time, normalized to ACT1.

Figure 5: GFP expression in strains with wild type or mutant histone $\mathrm{H} 4$.

A: $\quad$ Boxplots of GFP expression from silenced loci in strains expressing WT and mutant histone $\mathrm{H} 4 \mathrm{~K} 16 \mathrm{Q}$ alleles

Cells were grown in rich medium, imaged using a fluorescence microscope and the amount of fluorescence in each cell was quantitated and plotted as a box plot. For each sample, GFP fluorescence was measured in greater than 100 cells.

B: $\quad$ Fluorescence measurements of GFP at $H M L$ following switching the histone $\mathrm{H} 4$ cassettes 
A wild type histone HA-H4 cassette was switched to a wild type Myc-H4 cassette in G1 arrested cells and silencing at HML::GFP was monitored in the cells after their release from the cell cycle arrest.

Figure 6:

Boxplots of GFP expression at $H M L$ and $H M R$ as a function of time after switching the histone $\mathrm{H} 4$ cassettes

GFP fluorescence was measured as a function of time in strains with modified $H M L$ and HMR loci containing GFP under the control of either the URA3 UAS enhancer/promoter or the alpha2 UAS enhancer/promoter. Cells were arrested in $\mathrm{G} 1$, the histone $\mathrm{H} 4$ cassette was switched from wild type $\mathrm{H} 4$ to mutant $\mathrm{H} 4 \mathrm{~K} 16 \mathrm{Q}$ and cells were the released from the arrest. GFP fluorescence was measured as cells progressed through the cell cycle.

Figure 7:

Boxplots of GFP expression at the Telomere and HML following switching the histone cassette

A: $\quad$ GFP fluorescence measured as a function of time in strains with TEL $7 L:: U R A 3 p-$ GFP.

B: $\quad$ GFP fluorescence was measured as a function of time in strains with HML::URA3p-GFP but also containing the wild type copy of the HHT1-HHF1 locus. 
bioRxiv preprint doi: https://doi.org/10.1101/2020.11.17.386896; this version posted November 17,2020 . The copyright holder for this preprint

(which was not certified by peer review) is the author/funder, who has granted bioRxiv a license to display the preprint in perpetuity. It is made available under aCC-BY-NC-ND 4.0 International license.

\section{Acknowledgements:}

This work was supported in part by a grant from the NIH to RTK (GM078068) and (T32GM008646) to KW. We would also like to thank J. Rine for providing us with specific yeast strains. We would like to thank N. Bhalla for the use of her fluorescence microscope and the UCSC cytometry facility funded by the CIRM Shared Stem Cell Facility grant to UCSC (CL100506) for help with fluorescence cytometry. 


\section{References}

Ai, X., and Parthun, M.R. (2004). The nuclear Hat1p/Hat2p complex: a molecular link between type B histone acetyltransferases and chromatin assembly. Mol Cell 14, 195-205.

Almouzni, G., Clark, D.J., Mechali, M., and Wolffe, A.P. (1990). Chromatin assembly on replicating DNA in vitro. Nucleic Acids Res 18, 5767-5774.

Annunziato, A.T. (2015). The Fork in the Road: Histone Partitioning During DNA Replication. Genes (Basel) 6, 353-371.

Annunziato, A.T., and Seale, R.L. (1983). Histone deacetylation is required for the maturation of newly replicated chromatin. J Biol Chem 258, 12675-12684.

Aparicio, O.M., and Gottschling, D.E. (1994). Overcoming telomeric silencing: a trans-activator competes to establish gene expression in a cell cycle-dependent way. Genes Dev 8, 1133-1146. Bar-Ziv, R., Voichek, Y., and Barkai, N. (2016). Chromatin dynamics during DNA replication. Genome Res 26, 1245-1256.

Behrouzi, R., Lu, C., Currie, M.A., Jih, G., Iglesias, N., and Moazed, D. (2016). Heterochromatin assembly by interrupted Sir3 bridges across neighboring nucleosomes. eLife 5.

Benson, L.J., Gu, Y., Yakovleva, T., Tong, K., Barrows, C., Strack, C.L., Cook, R.G., Mizzen, C.A., and Annunziato, A.T. (2006). Modifications of H3 and H4 during chromatin replication, nucleosome assembly, and histone exchange. J Biol Chem 281, 9287-9296.

Carmen, A.A., Milne, L., and Grunstein, M. (2002). Acetylation of the yeast histone H4 N terminus regulates its binding to heterochromatin protein SIR3. J Biol Chem 277, 4778-4781. Cheng, T.H., and Gartenberg, M.R. (2000). Yeast heterochromatin is a dynamic structure that requires silencers continuously. Genes Dev 14, 452-463.

Cheng, T.H., Li, Y.C., and Gartenberg, M.R. (1998). Persistence of an alternate chromatin structure at silenced loci in the absence of silencers. Proc Natl Acad Sci U S A 95, 5521-5526. Cheutin, T., McNairn, A.J., Jenuwein, T., Gilbert, D.M., Singh, P.B., and Misteli, T. (2003). Maintenance of Stable Heterochromatin Domains by Dynamic HP1 Binding. Science 299, 721725.

Chien, C.T., Buck, S., Sternglanz, R., and Shore, D. (1993). Targeting of SIR1 protein establishes transcriptional silencing at HM loci and telomeres in yeast. Cell 75, 531-541.

Cole, H.A., Howard, B.H., and Clark, D.J. (2012a). Genome-wide mapping of nucleosomes in yeast using paired-end sequencing. Methods Enzymol 513, 145-168.

Cole, H.A., Nagarajavel, V., and Clark, D.J. (2012b). Perfect and imperfect nucleosome positioning in yeast. Biochim Biophys Acta 1819, 639-643.

Dhillon, N., Oki, M., Szyjka, S.J., Aparicio, O.M., and Kamakaka, R.T. (2006). H2A.Z functions to regulate progression through the cell cycle. Mol Cell Biol 26, 489-501.

Dhillon, N., Raab, J., Guzzo, J., Szyjka, S.J., Gangadharan, S., Aparicio, O.M., Andrews, B., and Kamakaka, R.T. (2009). DNA polymerase epsilon, acetylases and remodellers cooperate to form a specialized chromatin structure at a tRNA insulator. Embo J 28, 2583-2600.

Dion, M.F., Kaplan, T., Kim, M., Buratowski, S., Friedman, N., and Rando, O.J. (2007). Dynamics of replication-independent histone turnover in budding yeast. Science 315, 1405-1408.

Dodson, A.E., and Rine, J. (2015). Heritable capture of heterochromatin dynamics in Saccharomyces cerevisiae. eLife 4, e05007.

Donze, D., Adams, C.R., Rine, J., and Kamakaka, R.T. (1999). The boundaries of the silenced HMR domain in Saccharomyces cerevisiae. Genes Dev 13, 698-708. 
Ehrentraut, S., Hassler, M., Oppikofer, M., Kueng, S., Weber, J.M., Mueller, J.W., Gasser, S.M., Ladurner, A.G., and Ehrenhofer-Murray, A.E. (2011). Structural basis for the role of the Sir3 $A A A+$ domain in silencing: interaction with Sir4 and unmethylated histone H3K79. Genes Dev 25, 1835-1846.

Eriksson, P.R., Ganguli, D., Nagarajavel, V., and Clark, D.J. (2012). Regulation of histone gene expression in budding yeast. Genetics 191, 7-20.

Festenstein, R., Pagakis, S.N., Hiragami, K., Lyon, D., Verreault, A., Sekkali, B., and Kioussis, D. (2003). Modulation of heterochromatin protein 1 dynamics in primary Mammalian cells.

Science 299, 719-721.

Fox, C.A., Ehrenhofer-Murray, A.E., Loo, S., and Rine, J. (1997). The origin recognition complex, SIR1, and the $S$ phase requirement for silencing. Science 276, 1547-1551.

Friedman, K.L., Raghuraman, M.K., Fangman, W.L., and Brewer, B.J. (1995). Analysis of the temporal program of replication initiation in yeast chromosomes. J Cell Sci Suppl 19, 51-58. Gartenberg, M.R., and Smith, J.S. (2016). The Nuts and Bolts of Transcriptionally Silent Chromatin in Saccharomyces cerevisiae. Genetics 203, 1563-1599.

Gasser, R., Koller, T., and Sogo, J.M. (1996). The stability of nucleosomes at the replication fork. J Mol Biol 258, 224-239.

Ghidelli, S., Donze, D., Dhillon, N., and Kamakaka, R.T. (2001). Sir2p exists in two nucleosomebinding complexes with distinct deacetylase activities. Embo J 20, 4522-4535.

Gottschling, D.E., Aparicio, O.M., Billington, B.L., and Zakian, V.A. (1990). Position effect at S. cerevisiae telomeres: reversible repression of Pol II transcription. Cell 63, 751-762.

Gunjan, A., and Verreault, A. (2003). A Rad53 kinase-dependent surveillance mechanism that regulates histone protein levels in S. cerevisiae. Cell 115, 537-549.

Han, M., Kim, U.J., Kayne, P., and Grunstein, M. (1988). Depletion of histone H4 and nucleosomes activates the PHO5 gene in Saccharomyces cerevisiae. Embo J 7, 2221-2228.

Hecht, A., Laroche, T., Strahl-Bolsinger, S., Gasser, S.M., and Grunstein, M. (1995). Histone H3 and $\mathrm{H} 4 \mathrm{~N}$-termini interact with SIR3 and SIR4 proteins: a molecular model for the formation of heterochromatin in yeast. Cell $80,583-592$.

Hecht, A., Strahl-Bolsinger, S., and Grunstein, M. (1996). Spreading of transcriptional repressor SIR3 from telomeric heterochromatin. Nature 383, 92-96.

Huang, C., Xu, M., and Zhu, B. (2013). Epigenetic inheritance mediated by histone lysine methylation: maintaining transcriptional states without the precise restoration of marks? Philos Trans R Soc Lond B Biol Sci 368, 20110332.

Hyland, E.M., Cosgrove, M.S., Molina, H., Wang, D., Pandey, A., Cottee, R.J., and Boeke, J.D. (2005). Insights into the role of histone $\mathrm{H} 3$ and histone $\mathrm{H} 4$ core modifiable residues in Saccharomyces cerevisiae. Mol Cell Biol 25, 10060-10070.

Jackson, V., and Chalkley, R. (1985). Histone segregation on replicating chromatin. Biochemistry 24, 6930-6938.

Johnson, L.M., Fisher-Adams, G., and Grunstein, M. (1992). Identification of a non-basic domain in the histone $\mathrm{H} 4 \mathrm{~N}$-terminus required for repression of the yeast silent mating loci. Embo J 11 , 2201-2209.

Johnson, L.M., Kayne, P.S., Kahn, E.S., and Grunstein, M. (1990). Genetic evidence for an interaction between SIR3 and histone $\mathrm{H} 4$ in the repression of the silent mating loci in Saccharomyces cerevisiae. Proc Natl Acad Sci U S A 87, 6286-6290. 
Kayne, P.S., Kim, U.J., Han, M., Mullen, J.R., Yoshizaki, F., and Grunstein, M. (1988). Extremely conserved histone $\mathrm{H} 4 \mathrm{~N}$ terminus is dispensable for growth but essential for repressing the silent mating loci in yeast. Cell 55, 27-39.

Kirkland, J.G., and Kamakaka, R.T. (2013). Long-range heterochromatin association is mediated by silencing and double-strand DNA break repair proteins. J Cell Biol 201, 809-826.

Kitada, T., Schleker, T., Sperling, A.S., Xie, W., Gasser, S.M., and Grunstein, M. (2011). gammaH2A is a component of yeast heterochromatin required for telomere elongation. Cell Cycle 10, 293-300.

Kuo, M.H., Zhou, J., Jambeck, P., Churchill, M.E., and Allis, C.D. (1998). Histone acetyltransferase activity of yeast Gcn5p is required for the activation of target genes in vivo. Genes Dev 12, 627639.

Lau, A., Blitzblau, H., and Bell, S.P. (2002). Cell-cycle control of the establishment of mating-type silencing in S. cerevisiae. Genes Dev 16, 2935-2945.

Li, Y.C., Cheng, T.H., and Gartenberg, M.R. (2001). Establishment of transcriptional silencing in the absence of DNA replication. Science 291, 650-653.

Lin, Y.Y., Qi, Y., Lu, J.Y., Pan, X., Yuan, D.S., Zhao, Y., Bader, J.S., and Boeke, J.D. (2008). A comprehensive synthetic genetic interaction network governing yeast histone acetylation and deacetylation. Genes Dev 22, 2062-2074.

Ling, X., Harkness, T.A., Schultz, M.C., Fisher-Adams, G., and Grunstein, M. (1996). Yeast histone $\mathrm{H} 3$ and $\mathrm{H} 4$ amino termini are important for nucleosome assembly in vivo and in vitro:

redundant and position-independent functions in assembly but not in gene regulation. Genes Dev 10, 686-699.

Litt, M.D., Simpson, M., Recillas-Targa, F., Prioleau, M.N., and Felsenfeld, G. (2001). Transitions in histone acetylation reveal boundaries of three separately regulated neighboring loci. Embo J 20, 2224-2235.

Liu, C., and Lustig, A.J. (1996). Genetic analysis of Rap1p/Sir3p interactions in telomeric and HML silencing in Saccharomyces cerevisiae. Genetics 143, 81-93.

Lucchini, R., Wellinger, R.E., and Sogo, J.M. (2001). Nucleosome positioning at the replication fork. Embo J 20, 7294-7302.

Luo, K., Vega-Palas, M.A., and Grunstein, M. (2002). Rap1-Sir4 binding independent of other Sir, $\mathrm{yKu}$, or histone interactions initiates the assembly of telomeric heterochromatin in yeast. Genes Dev 16, 1528-1539.

MacAlpine, D.M., and Almouzni, G. (2013). Chromatin and DNA replication. Cold Spring Harb Perspect Biol 5, a010207.

Maillet, L., Boscheron, C., Gotta, M., Marcand, S., Gilson, E., and Gasser, S.M. (1996). Evidence for silencing compartments within the yeast nucleus: a role for telomere proximity and Sir protein concentration in silencer-mediated repression. Genes Dev 10, 1796-1811.

Masumoto, H., Hawke, D., Kobayashi, R., and Verreault, A. (2005). A role for cell-cycle-regulated histone H3 lysine 56 acetylation in the DNA damage response. Nature 436, 294-298.

Meeks-Wagner, D., and Hartwell, L.H. (1986). Normal stoichiometry of histone dimer sets is necessary for high fidelity of mitotic chromosome transmission. Cell 44, 43-52.

Mello, J.A., and Almouzni, G. (2001). The ins and outs of nucleosome assembly. Curr Opin Genet Dev 11, 136-141. 
Millar, C.B., Kurdistani, S.K., and Grunstein, M. (2004). Acetylation of yeast histone H4 lysine 16: a switch for protein interactions in heterochromatin and euchromatin. Cold Spring Harb Symp Quant Biol 69, 193-200.

Miller, A.M., and Nasmyth, K.A. (1984). Role of DNA replication in the repression of silent mating type loci in yeast. Nature 312, 247-251.

Misteli, T., Gunjan, A., Hock, R., Bustin, M., and Brown, D.T. (2000). Dynamic binding of histone $\mathrm{H} 1$ to chromatin in living cells. Nature $408,877-881$.

Mukhopadhyay, S., and Sengupta, A.M. (2013). The role of multiple marks in epigenetic silencing and the emergence of a stable bivalent chromatin state. PLoS Comput Biol 9, e1003121.

Nelson, J.D., Denisenko, O., Sova, P., and Bomsztyk, K. (2006). Fast chromatin immunoprecipitation assay. Nucleic Acids Res 34, e2.

O'Kane, C.J., and Hyland, E.M. (2019). Yeast epigenetics: the inheritance of histone modification states. Biosci Rep 39.

Oki, M., and Kamakaka, R.T. (2005). Barrier Function at HMR. Mol Cell 19, 707-716.

Onishi, M., Liou, G.G., Buchberger, J.R., Walz, T., and Moazed, D. (2007). Role of the conserved Sir3-BAH domain in nucleosome binding and silent chromatin assembly. Mol Cell 28, 10151028.

Osborne, E.A., Dudoit, S., and Rine, J. (2009). The establishment of gene silencing at single-cell resolution. Nat Genet 41, 800-806.

Osborne, E.A., Hiraoka, Y., and Rine, J. (2011). Symmetry, asymmetry, and kinetics of silencing establishment in Saccharomyces cerevisiae revealed by single-cell optical assays. Proc Natl Acad Sci U S A 108, 1209-1216.

Otto, G. (2019). Enhancers and promoters regulate burst kinetics. Nat Rev Mol Cell Biol 20, 134135.

Pelechano, V., Chavez, S., and Perez-Ortin, J.E. (2010). A complete set of nascent transcription rates for yeast genes. PLoS One 5, e15442.

Pillus, L., and Rine, J. (1989). Epigenetic inheritance of transcriptional states in S. cerevisiae. Cell 59, 637-647.

Radman-Livaja, M., Verzijlbergen, K.F., Weiner, A., van Welsem, T., Friedman, N., Rando, O.J., and van Leeuwen, F. (2011). Patterns and mechanisms of ancestral histone protein inheritance in budding yeast. PLoS Biol 9, e1001075.

Raghuraman, M.K., Winzeler, E.A., Collingwood, D., Hunt, S., Wodicka, L., Conway, A., Lockhart, D.J., Davis, R.W., Brewer, B.J., and Fangman, W.L. (2001). Replication dynamics of the yeast genome. Science 294, 115-121.

Ravindra, A., Weiss, K., and Simpson, R.T. (1999). High-resolution structural analysis of chromatin at specific loci: Saccharomyces cerevisiae silent mating-type locus HMRa. Mol Cell Biol 19, 7944-7950.

Renauld, H., Aparicio, O.M., Zierath, P.D., Billington, B.L., Chhablani, S.K., and Gottschling, D.E. (1993). Silent domains are assembled continuously from the telomere and are defined by promoter distance and strength, and by SIR3 dosage. Genes and Dev. 7, 1133-1145. Riba, A., Di Nanni, N., Mittal, N., Arhne, E., Schmidt, A., and Zavolan, M. (2019). Protein synthesis rates and ribosome occupancies reveal determinants of translation elongation rates. Proc Natl Acad Sci U S A 116, 15023-15032. 
Rodriguez, J., and Larson, D.R. (2020). Transcription in Living Cells: Molecular Mechanisms of Bursting. Annu Rev Biochem 89, 189-212.

Rusche, L.N., Kirchmaier, A.L., and Rine, J. (2002). Ordered nucleation and spreading of silenced chromatin in Saccharomyces cerevisiae. Mol Biol Cell 13, 2207-2222.

Schmitt, M.E., Brown, T.A., and Trumpower, B.L. (1990). A rapid and simple method for preparation of RNA from Saccharomyces cerevisiae. Nucleic Acids Res 18, 3091-3092. Shahbazian, M.D., and Grunstein, M. (2007). Functions of site-specific histone acetylation and deacetylation. Annu Rev Biochem 76, 75-100.

Shei, G.J., and Broach, J.R. (1995). Yeast silencers can act as orientation-dependent gene inactivation centers that respond to environmental signals. Mol Cell Biol 15, 3496-3506.

Sneppen, K., and Dodd, I.B. (2012). A simple histone code opens many paths to epigenetics. PLoS Comput Biol 8, e1002643.

Sneppen, K., and Dodd, I.B. (2015). Cooperative stabilization of the SIR complex provides robust epigenetic memory in a model of SIR silencing in Saccharomyces cerevisiae. Epigenetics 10, 293302.

Sobel, R.E., Cook, R.G., Perry, C.A., Annunziato, A.T., and Allis, C.D. (1995). Conservation of deposition-related acetylation sites in newly synthesized histones $\mathrm{H} 3$ and $\mathrm{H} 4$. Proc Natl Acad Sci U S A 92, 1237-1241.

Sogo, J.M., Stahl, H., Koller, T., and Knippers, R. (1986). Structure of replicating simian virus 40 minichromosomes. The replication fork, core histone segregation and terminal structures. J Mol Biol 189, 189-204.

Solomon, M.J., and Varshavsky, A. (1987). A nuclease-hypersensitive region forms de novo after chromosome replication. Mol Cell Biol 7, 3822-3825.

Sussel, L., Vannier, D., and Shore, D. (1993). Epigenetic switching of transcriptional states: cisand trans-acting factors affecting establishment of silencing at the HMR locus in Saccharomyces cerevisiae. Mol Cell Biol 13, 3919-3928.

Thurtle, D.M., and Rine, J. (2014). The molecular topography of silenced chromatin in Saccharomyces cerevisiae. Genes Dev 28, 245-258.

Valenzuela, L., Dhillon, N., Dubey, R.N., Gartenberg, M.R., and Kamakaka, R.T. (2008). Longrange communication between the silencers of HMR. Mol Cell Biol 28, 1924-1935.

Valenzuela, L., Dhillon, N., and Kamakaka, R.T. (2009). Transcription independent insulation at TFIIIC-dependent insulators. Genetics 183, 131-148.

Vasseur, P., Tonazzini, S., Ziane, R., Camasses, A., Rando, O.J., and Radman-Livaja, M. (2016). Dynamics of Nucleosome Positioning Maturation following Genomic Replication. Cell Rep 16, 2651-2665.

Wang, F., Li, G., Altaf, M., Lu, C., Currie, M.A., Johnson, A., and Moazed, D. (2013).

Heterochromatin protein Sir3 induces contacts between the amino terminus of histone $\mathrm{H} 4$ and nucleosomal DNA. Proc Natl Acad Sci U S A 110, 8495-8500.

Wang, Y., Ni, T., Wang, W., and Liu, F. (2018). Gene transcription in bursting: a unified mode for realizing accuracy and stochasticity. Biol Rev Camb Philos Soc.

Waterborg, J.H. (2001). Dynamics of histone acetylation in Saccharomyces cerevisiae. Biochemistry 40, 2599-2605.

Waterborg, J.H. (2002). Dynamics of histone acetylation in vivo. A function for acetylation turnover? Biochem Cell Biol 80, 363-378. 
bioRxiv preprint doi: https://doi.org/10.1101/2020.11.17.386896; this version posted November 17,2020 . The copyright holder for this preprint

(which was not certified by peer review) is the author/funder, who has granted bioRxiv a license to display the preprint in perpetuity. It is made available under aCC-BY-NC-ND 4.0 International license.

Weiss, K., and Simpson, R.T. (1998). High-resolution structural analysis of chromatin at specific loci: Saccharomyces cerevisiae silent mating type locus HMLalpha. Mol Cell Biol 18, 5392-5403. $\mathrm{Xu}$, E.Y., Zawadzki, K.A., and Broach, J.R. (2006). Single-cell observations reveal intermediate transcriptional silencing states. Mol Cell 23, 219-229.

$\mathrm{Yu}, \mathrm{Q}$., Olsen, L., Zhang, X., Boeke, J.D., and Bi, X. (2011). Differential contributions of histone H3 and $\mathrm{H} 4$ residues to heterochromatin structure. Genetics 188, 291-308. 
bioRxiv preprint doi: https://doi.org/10.1101/2020.11.17.386896; this version posted November 17, 2020. The copyright holder for this preprint (which was not certified by peer review) is the author/funder, who has granted bioRxiv a license to display the preprint in perpetuity. It is made available under aCC-BY-NC-ND 4.0 International license.
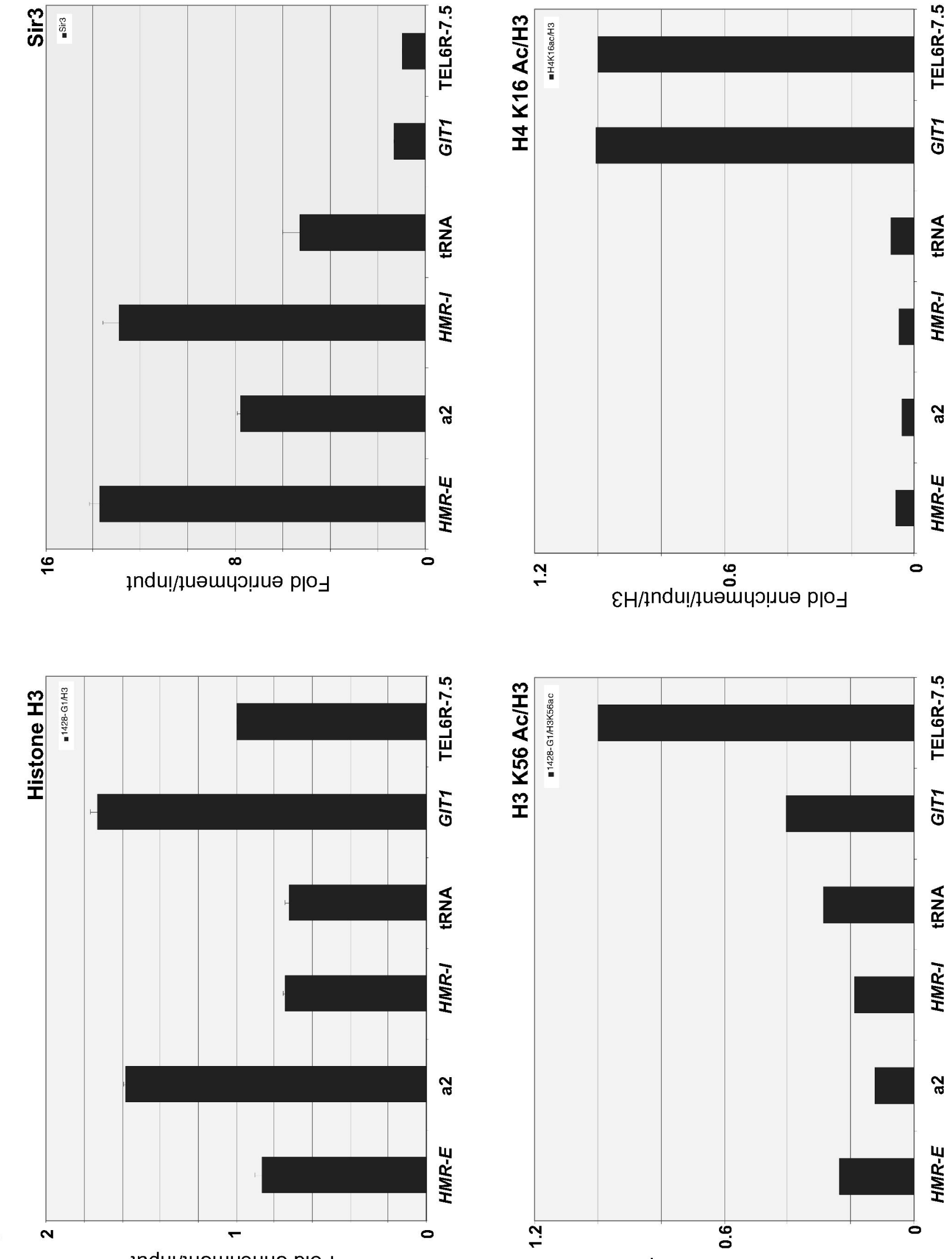

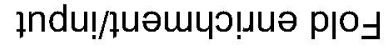

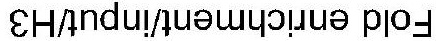


bioRxiv preprint doi: https://doi.org/10.1101/2020.11.17.386896; this version posted November 17, 2020. The copyright holder for this preprint (which was not certified by peer review) is the author/funder, who has granted bioRxiv a license to display the preprint in perpetuity. It is made available under aCC-BY-NC-ND 4.0 International license.
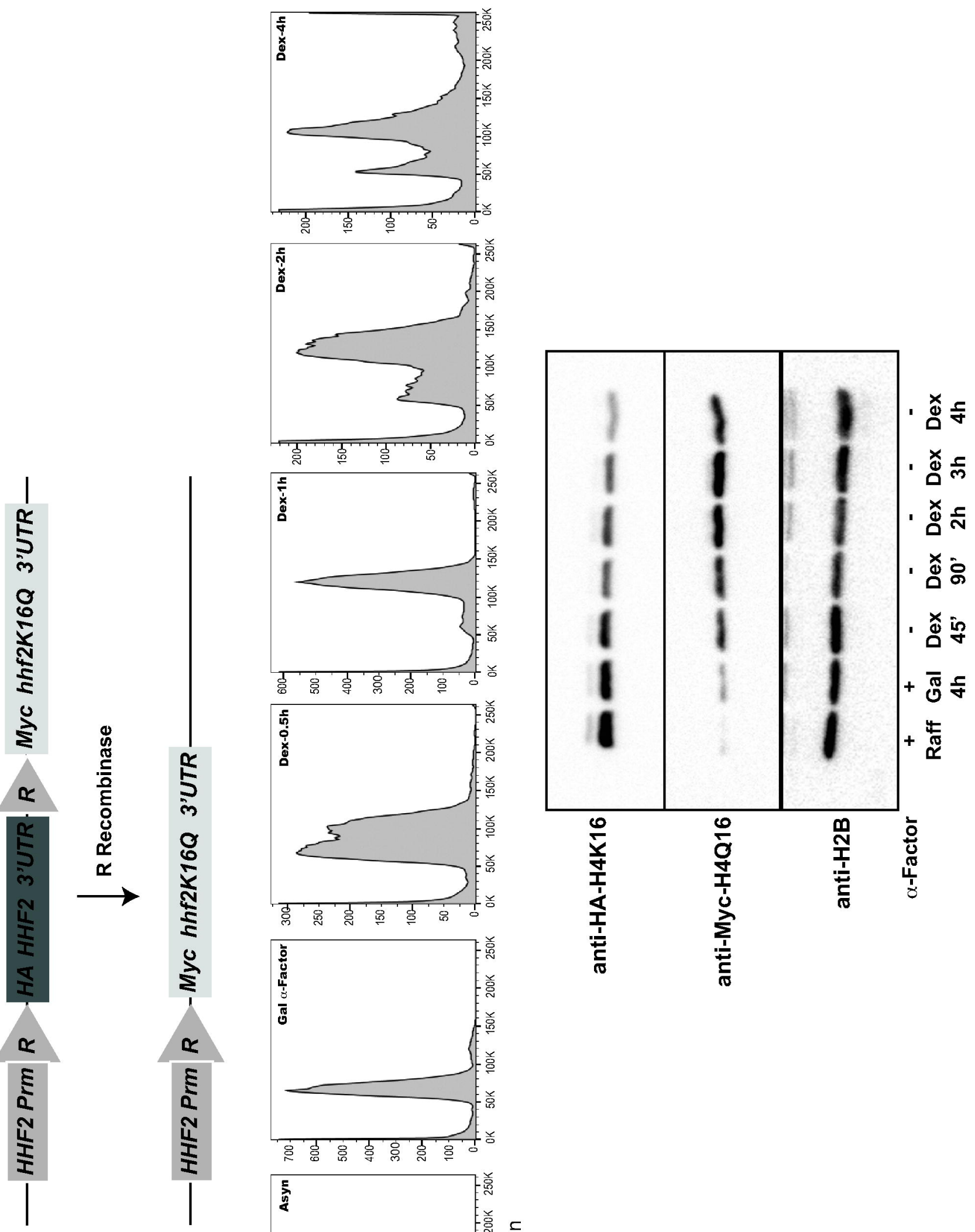

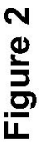

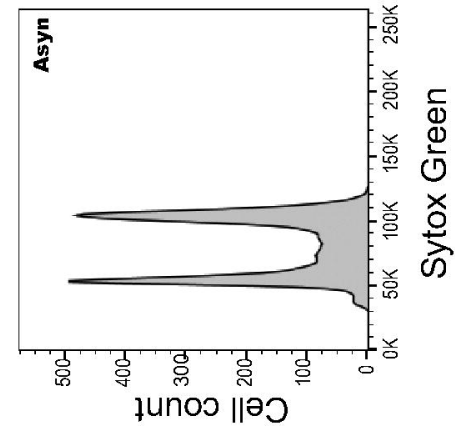

$\mathcal{U}$ 

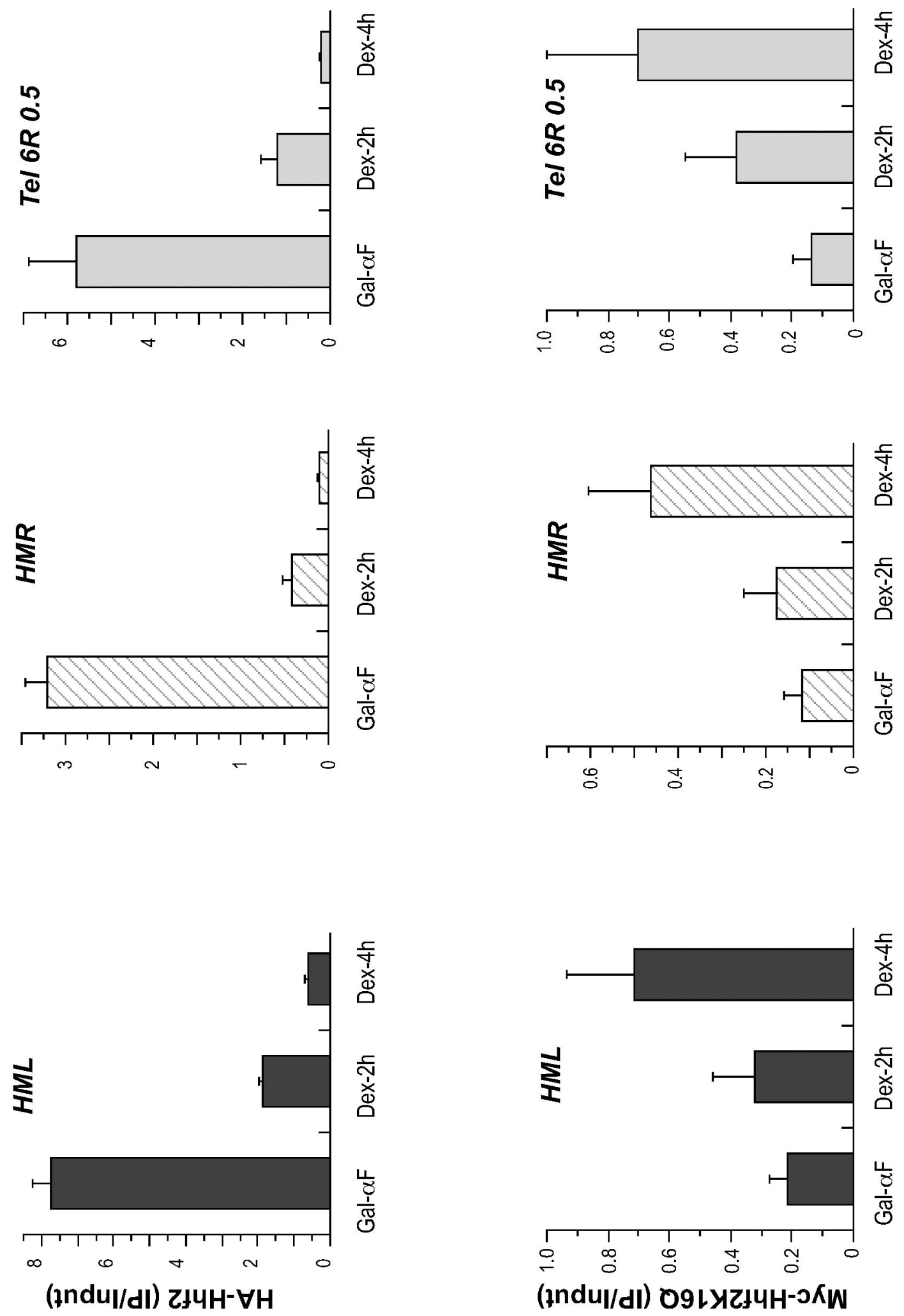
bioRxiv preprint doi: https://doi.org/10.1101/2020.11.17386896; this version posted November 17,2020 . The copyright holder for this preprint (which was not certified by peer review) is the author/funder, who has granted bioRxiv a license to display the preprint in perpetuity. It is made available under aCC-BY-NC-ND 4.0 International license.
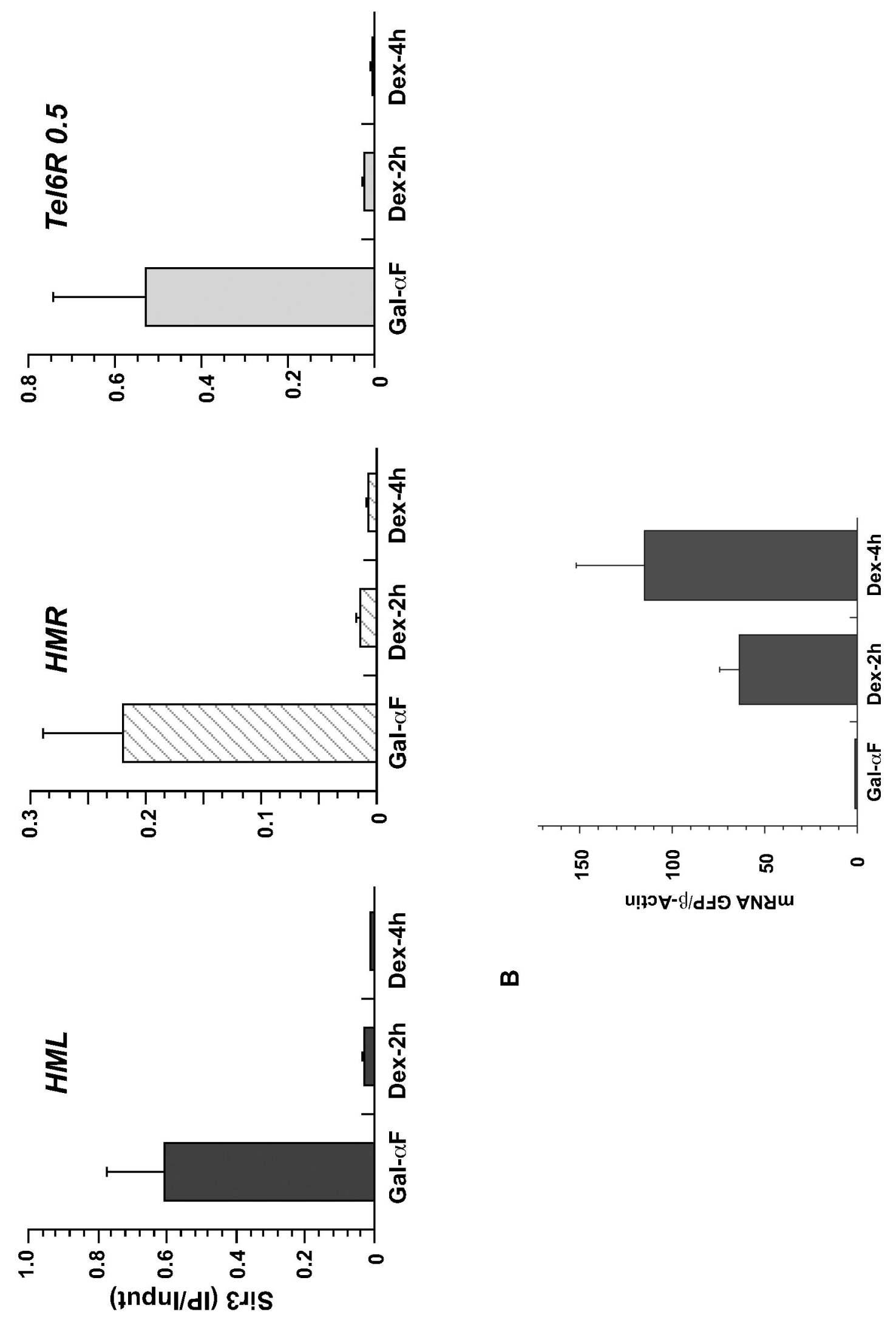

$m$ 
bioRxiv preprint doi: https://doi.org/10.1101/2020 11.17 386896; this version posted November 17, 2020. The copyright holder for this preprint (which was not certified by peer review) is the author/funder, who has granted bioRxiv a license to display the preprint in perpetuity. It is made available under aCC-BY-NC-ND 4.0 International license.
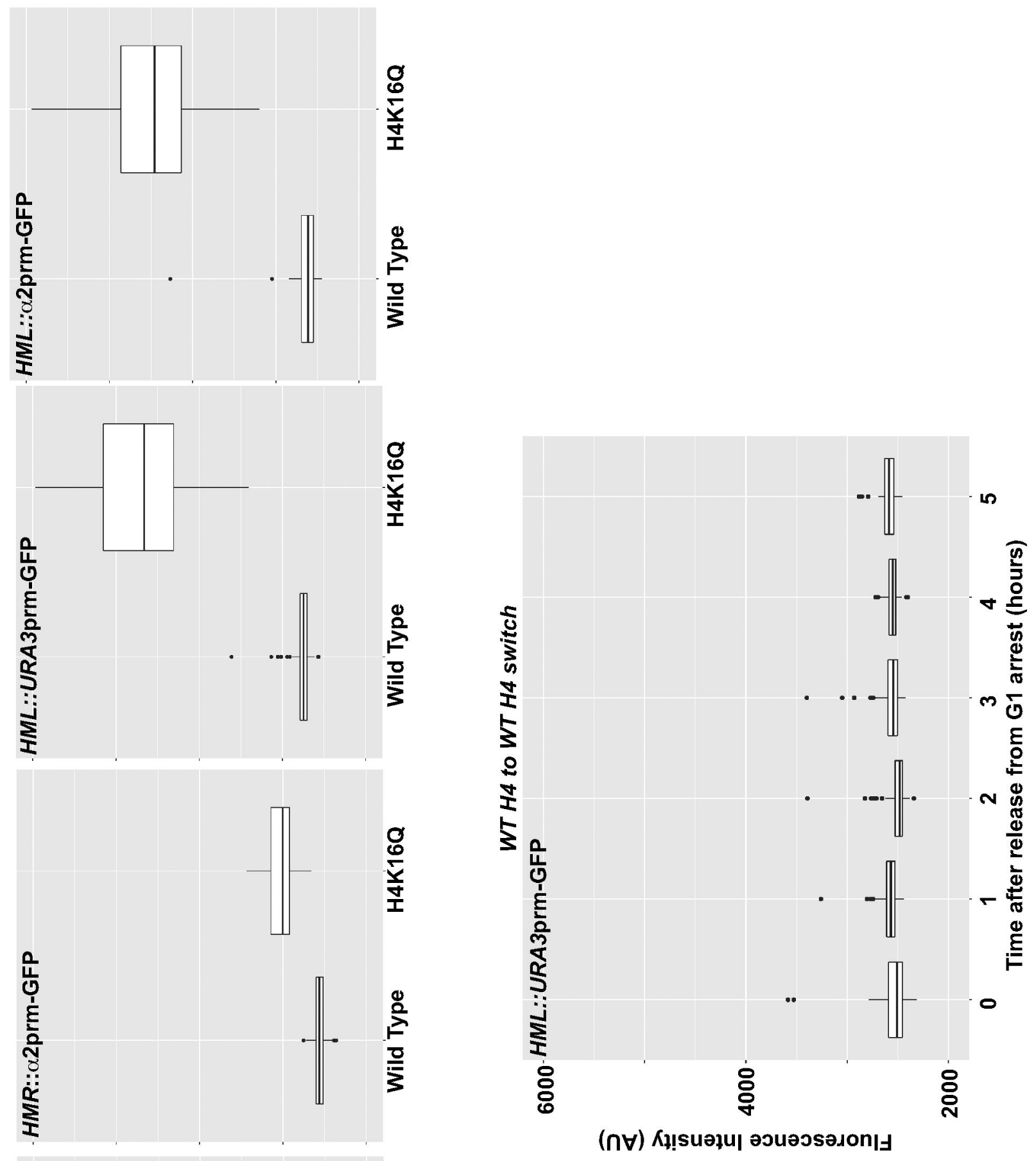

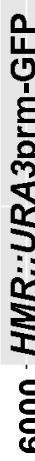

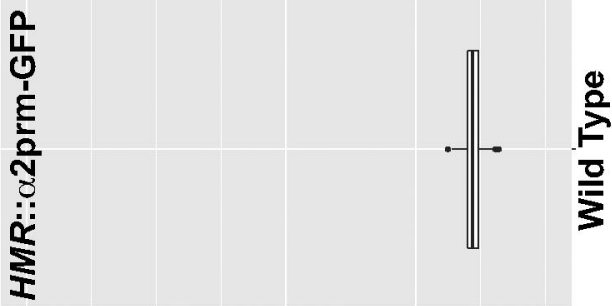

8
$\frac{0}{1}$
$\frac{1}{1}$

$\frac{\text { 를 }}{\frac{1}{2}}$
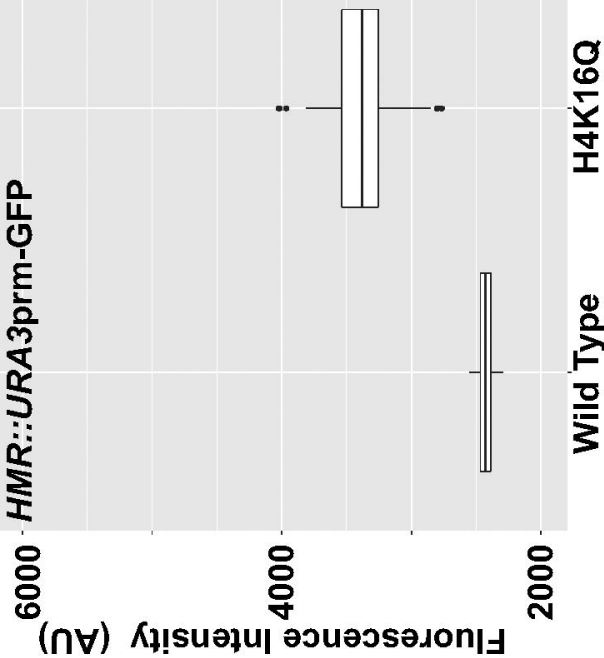

$\mathbf{m}$ 

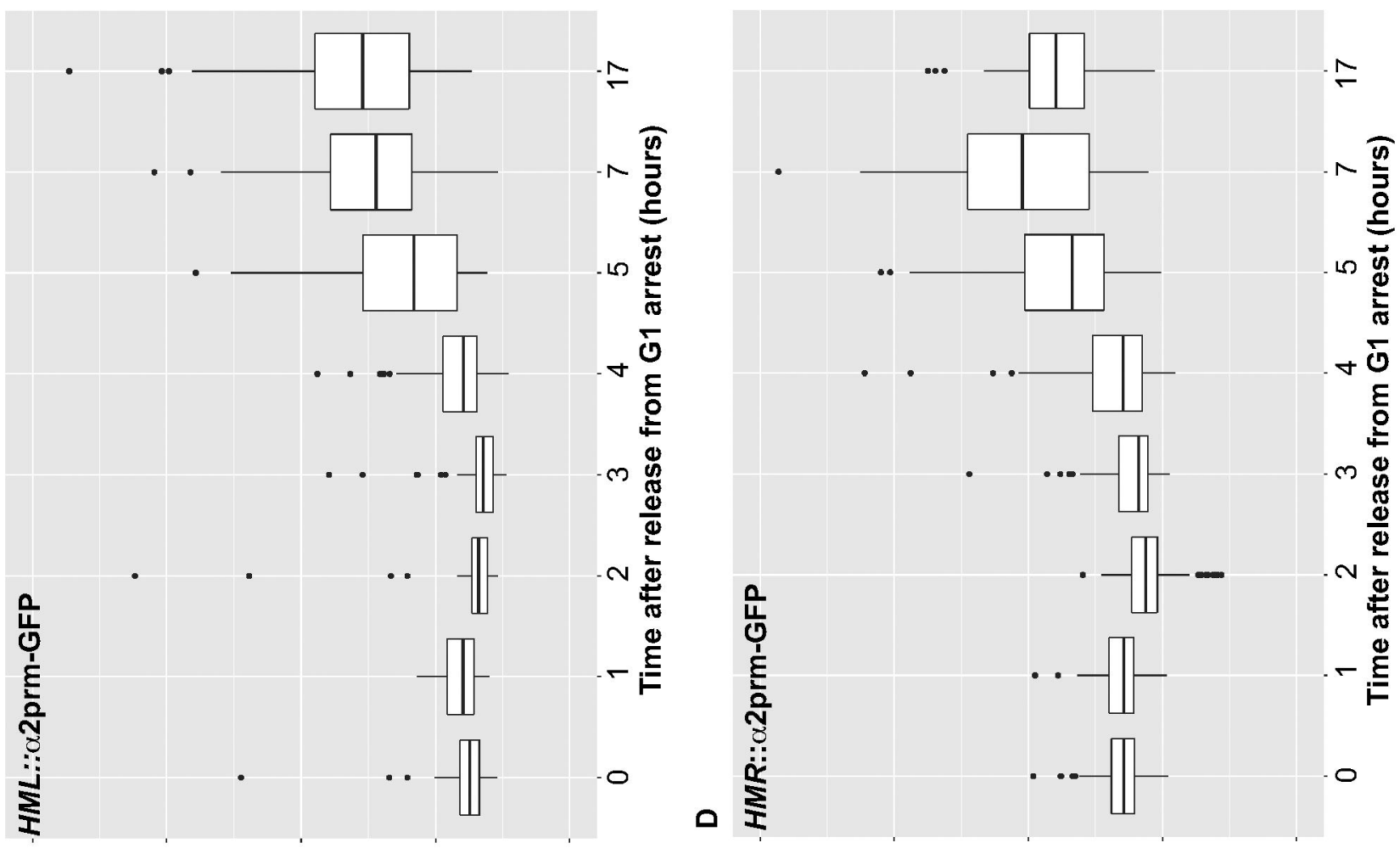
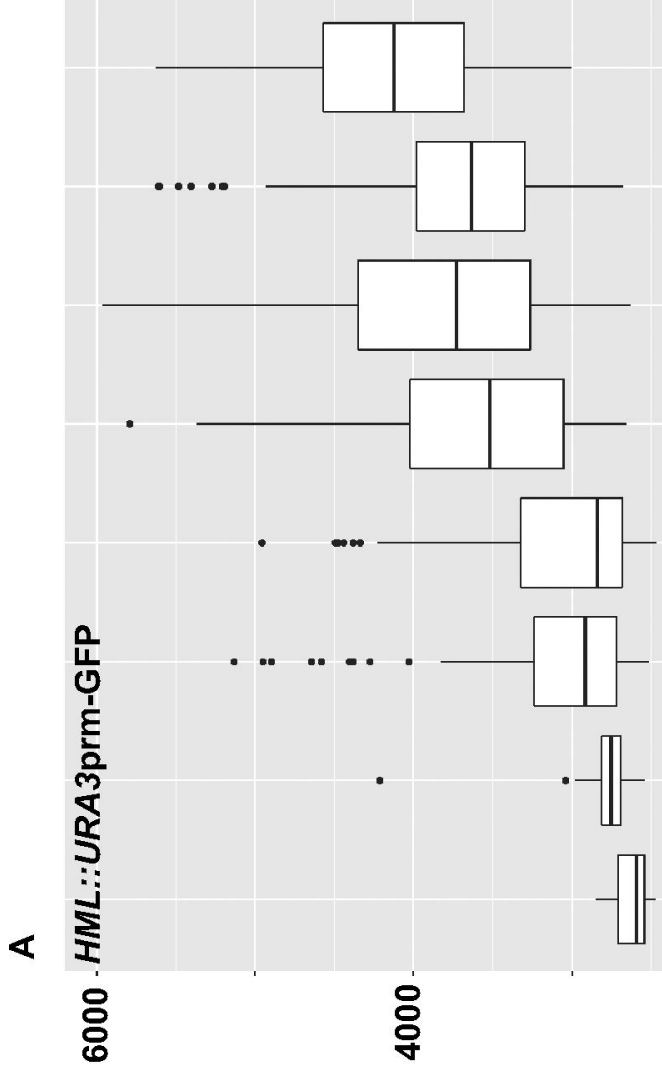

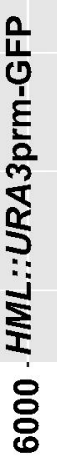

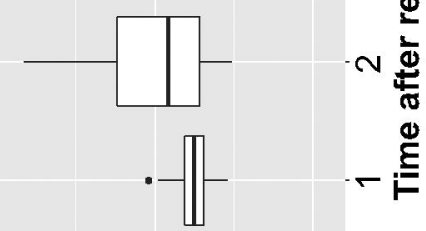

$\therefore$

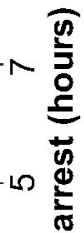

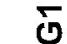

$\checkmark \frac{\varepsilon}{0}$

$m$

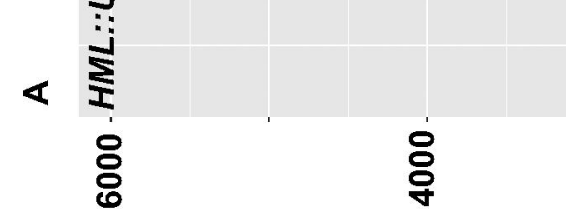

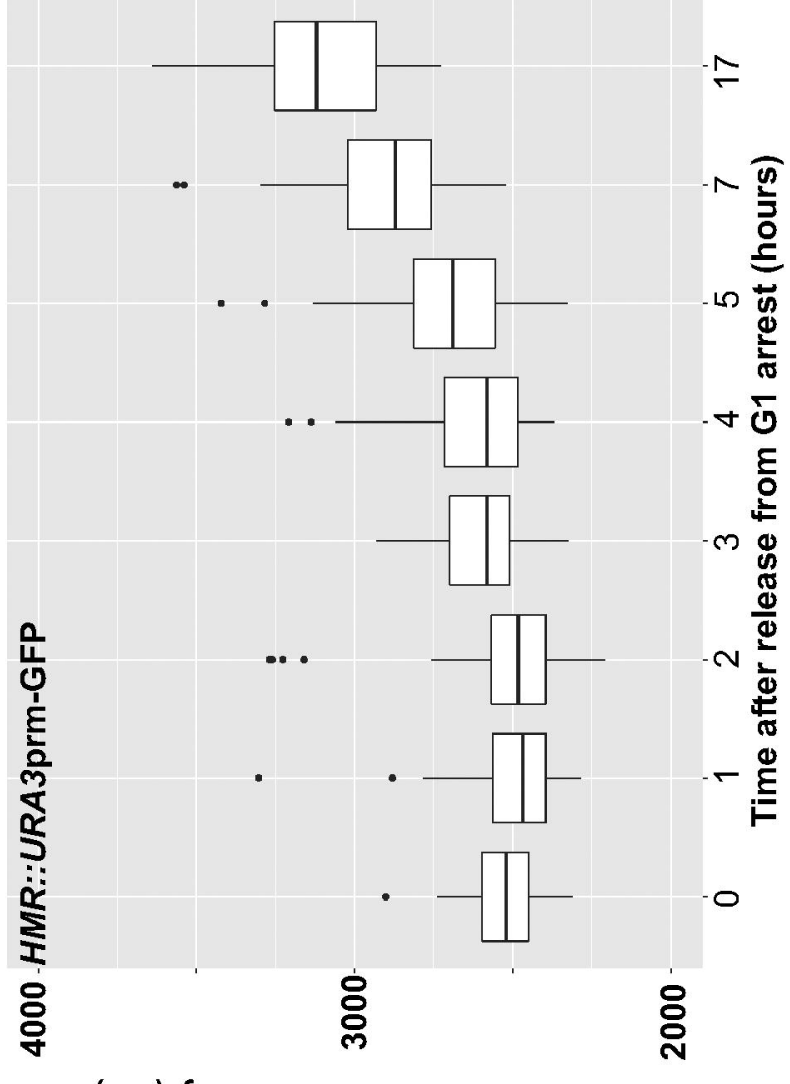

$-N$
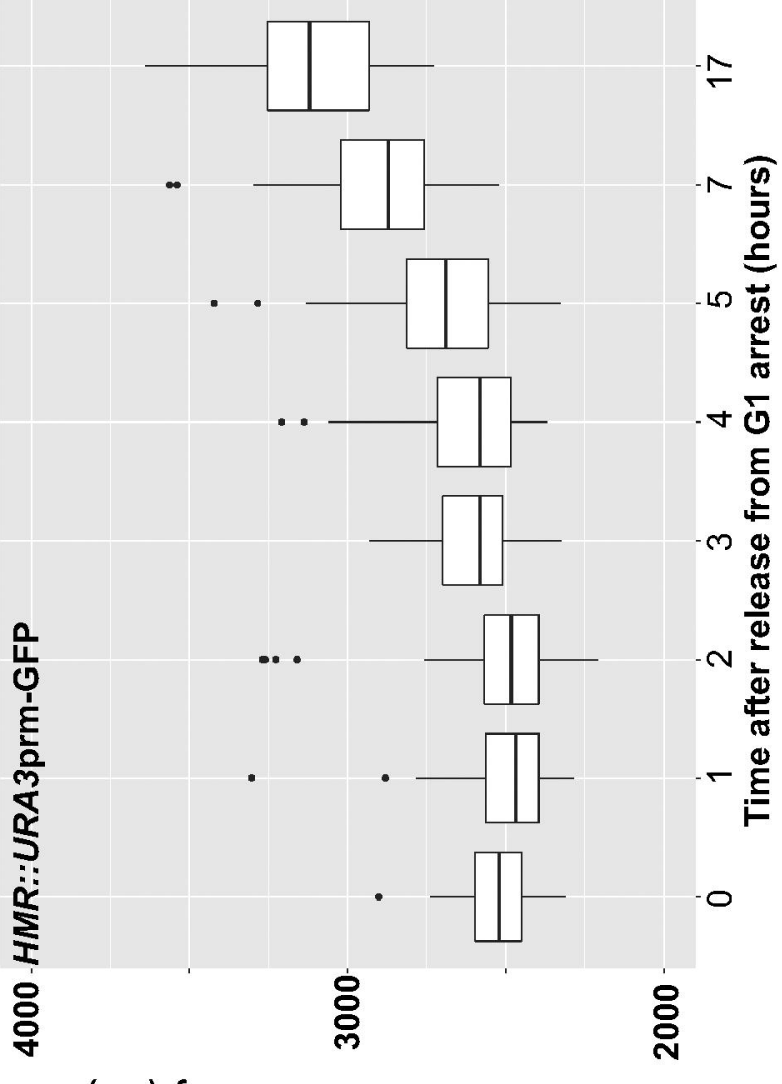

$\nabla \bar{O}$

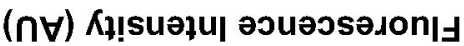


bioRxiv preprint doi: https://doi.org/10.1101/2020.11.17.386896; this version posted November 17, 2020. The copyright holder for this preprint (which was not certified by peer review) is the author/funder, who has granted bioRxiv a license to display the preprint in perpetuity. It is made available under aCC-BY-NC-ND 4.0 International license.

$\mathbf{m}$
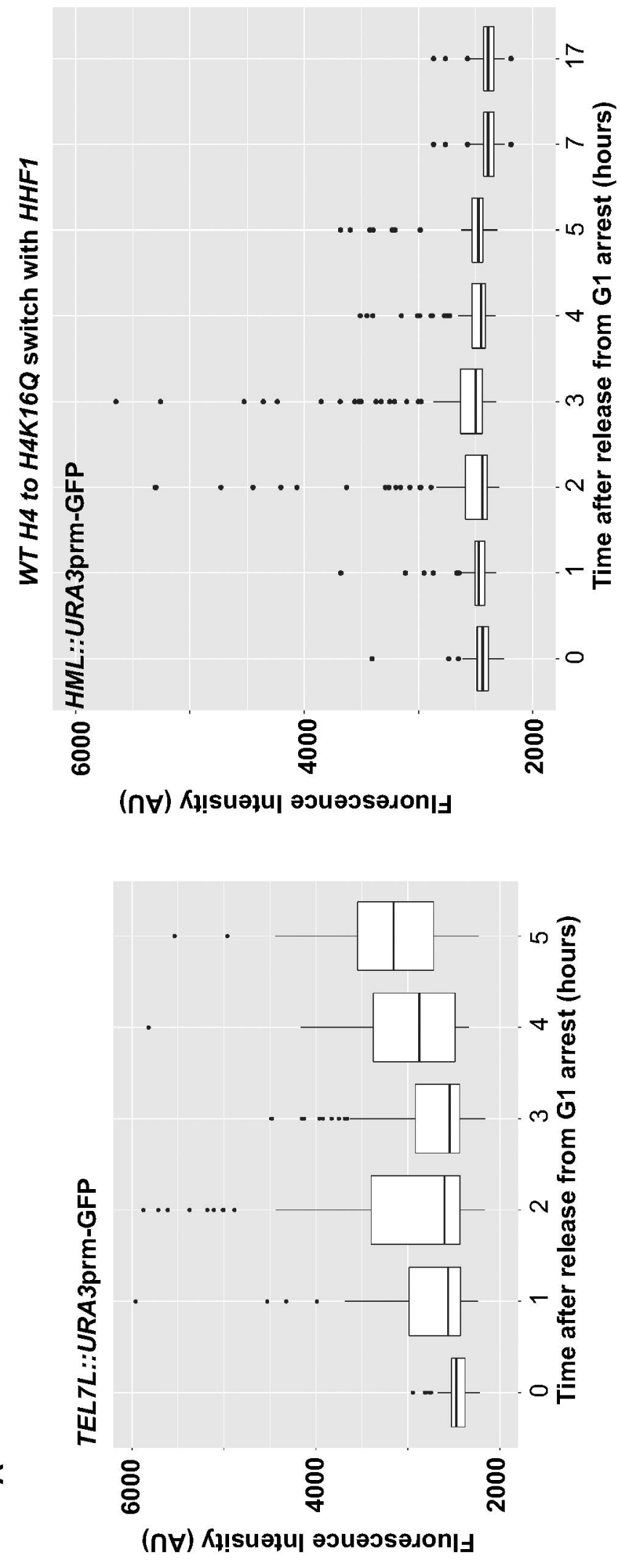